\title{
PERILAKU BELANJA ONLINE PADA IBU RUMAH TANGGA DISAAT PANDEMI COVID-19 ( STUDI KASUS IBU RUMAH TANGGA DI ANJUN KARAWANG )
}

\author{
${ }^{1}$ Neni Sumarni \\ ${ }^{2}$ Syifa Pramudita Faddila \\ ${ }^{3}$ Robby Fauji \\ neni.sumarni@ubpkarawang.ac.id, syifa.pramudita@ubpkarawang.ac.id \\ robby.fauji@ubpkarawang.ac.id
}

\begin{abstract}
Abstrak
Penyebaran wabah pandemi Covid-19 di negara Indonesia yang semakin cepat memang merubah interaksi antara bisnis dan pelanggan. Adanya kebijakan dari pemerintah terkait Covid-19 ini berupa larangan keluar masuk negara Indonesia, social distancing dan stay at home pada akhirnya merubah perilaku konsumen yang awalnya bebas melakukan transaksi bisnis maupun perdagangan yang secara offline berubah menjadi online. Penelitian ini bertujuan untuk mengetahui apakah para ibu rumah tangga wilayah Anjun melakukan pembelanjaan secara online disaat pandemic. Dalam penelitian deskriptif kuantitatif ini melibatkan sampel sebanyak 100 responden ibu-ibu rumah tangga di Anjun, Kabupaten Karawang. Hasil penelitian menunjukkan bahwa $83 \%$ responden sudah memiliki pengetahuan mengenai pembelanjaan online, sebanyak $72 \%$ ibu rumah tangga di Anjun melakukan pembelanjaan secara online di masa pandemi, dan $52 \%$ nya melakukan pembelanjaan online lebih dari dua kali dalam sebulan. Dengan alasan kesehatan dan menghindari tertularnya virus corona. Sehingga dapat disimpulkan bahwa banyak para konsumen atau pelanggan yang akhirnya merubah perilaku belanjanya menjadi online untuk menghindari wabah ini dan memudahkan dalam memperoleh barang-barang yang dibutuhkannya.
\end{abstract}

Kata Kunci: Perilaku Konsumen, Penjualan Online, Pandemi Covid-19.

\begin{abstract}
The increasingly rapid spread of the covid-19 pandemic outbreak in Indonesia has indedd changed the interaction between businesses and customers. There is a policy from the government regarding covid-19 in the form of a ban on entering and leaving the country of Indonesia, social distancing and staying at home in the end changing the behavior of consumers who are initially free to carry out business transaction or trade which turn offline to online. This study aims to determine whether yhe housewives of the Anjun region shop online during the pandemic. This quantitative descriptive study involved a sample of 100 housewives in Anjun, Karawang district. The results showed that $83 \%$ of respondents already have knowledge about online shopping, as many as 72 $\%$ of housewives in Anjun shop online during the pandemic, and $52 \%$ shop online more than twice a month. For health reasons and avoiding contracting the corona virus. So it can be concluded that many consumers or customers have finally changed their shopping behavior online toavoid this outbreak and make it easier to get the goods they nedd.
\end{abstract}

Key words : consumer behavior,online sales,covid pandemic 19 


\section{PENDAHULUAN}

Awal Munculnya Virus Baru yang menggemparkan Warga Dunia diakhir Tahun 2019 dinamai Covid-19 (Corona Virus Disease 2019) muncul dan dinyatakan sebagai Pandemi, menurut berbagai sumber bahwa Pandemi Virus Covid-19 pertama kali muncul ke permukaan ketika Tanggal 31 Desember 2019, sejak itu WHO (World Health Organization) Menerima Laporan dari Negara China bahwa ada Wabah di Kota Pelabuhan Wuhan dari Virus yang belum diketahui. Wabah ini meluas dengan sangat cepat ke berbagai Negara dalam dua minggu kemudian sehingga menjadi Pandemi Global merenggut korban meninggal dunia lebih dari 32.000.000 orang di 199 Negara. Pandemi Covid-19 ini diketahui masuk ke Indonesia pada Pertengahan Bulan Maret 2020 telah ditetapkan oleh Pemerintah pada Hari Sabtu, 14 Maret 2020 bahwa Negara Indonesia memasuki Masa Darurat Bencana dengan Jumlah Pasien Positif sebanyak \pm 20.000 .

Munculnya Pandemi Covid 19 di Negara Indonesia menjadi Global Virus Corona yang menimbulkan berbagai Masalah Kesehatan fisik, mental, spiritual dan ekonomi hingga menyebabkan pergeseran nilai-nilai sosial dan budaya. Fenomena tersebut memunculkan kepanikan di tengah Masyarakat. Sebagian besar orang yang tertular Covid-19 akan mengalami gejala ringan hingga sedang dan akan pulih dengan penanganan khusus. Virus yang menyebabkan Covid-19 terutama ditransmisikan cepat tersebar penularannya dari human to human dengan melalui Droplet (tetesan kecil) yang dihasilkan saat orang yang terinfeksi batuk, bersin, atau mengembuskan nafas. Droplet ini terlalu berat sehingga tidak bisa bertahan di udara. Droplet dengan cepat jatuh dan menempel pada lantai atau permukaan lainnya dapat tertular saat menghirup udara yang mengandung virus ketika berada terlalu dekat dengan orang yang sudah terinfeksi Covid-19, Serta dapat tertular saat menyentuh permukaan benda yang terkontaminasi lalu menyentuh mata, hidung, atau mulut.

Pemerintah Membuat Beragam Kebijakan untuk mengurangi bertambahnya penyebaran virus corona. Mulai dari kebijakan, larangan keluar masuk Negara Indonesia, larangan berkumpul, stay at home. Stay at home yaitu 
Isolasi Diri, social distancing, hingga Karantina Wilayah. Karantina Wilayah merupakan kebijakan yang di ambil dalam kondisi sangat darurat. Beberapa Kota dan Kabupaten telah memberlakukan Pembatasan Sosial Berskala Besar (PSBB) untuk mencegah penyebaran Virus Covid-19 harus dilakukan Social Distancing (Jarak Sosial) atau dikenal juga dengan upaya Lockdown (Karantina Wilayah).

Adanya wabah ini juga pada akhirnya merubah perilaku konsumen yang awalnya bebas melakukan transaksi bisnis maupun perdagangan yang secara offline berubah menjadi online. Banyak para konsusmen atau pelanggan yang akhirnya merubah perilaku belinya menjadi online untuk menghindari wabah ini dan memudahkan dalam memperoleh barang-barang yang dibutuhkannya. Perubahan perilaku konsumen untuk proses pembelian secara online juga dilakukan oleh para ibu rumah tangga yang berada di wilayah Anjun Karawang.

\section{METODE PENELITIAN}

\section{Jenis Penelitian}

Penelitian ini menggunakan metode deskriptif yaitu metode dimana prosedur pemecahan masalah yang diselidiki dengan menggambarkan atau melukiskan keadaan objek penelitian pada saat sekarang berdasarkan fakta fakta yang tampak atau sebagaimana adanya, yaitu dengan melihat kasus yang berkembang saat ini ( Nawawi \& Matini, 1992 - 27 ). Penelitian ini menggunakan kualitatif yang memiliki relasi dengan analisis data visual dan data verbal yang merefleksikan pengalaman.

\section{Waktu dan Tempat Penelitian}

Waktu penelitian di lakukan pada rentang waktu Mei-Agustus 2020, di Kampung Anjun Kanoman, Karawang Kulon, Karawang.

\section{Target/Subjek Penelitian}

Sampel penelitian yang diambil adalah 100 orang ibu rumah tangga yang berada di Kampung Anjun Kanoman RW 05 dan RW 12

\section{Prosedur Penelitian}

Prosedur penelitian yang dilakukan dengan melakukan penyebaran quisioner atau angket terhadap ibu rumah tangga, wawancara dilakukan pada 
beberapa ibu rumah tangga untuk melengkapi data yang ada. Kemudian ada juga wawancara yang dilakukan pada aparat desa unit terkecil yaitu Rukun Warga atau RW. Peneyebaran angket pertama dilakukan pada 30 orang responden untuk menguji validitas dan reliabilitas dari angket tersebut. Setelah teruji valid dan reliable kemudian dilakukan tahap selanjutnya yaitu dengan menyebarkan kembali kepada 70 orang responden ibu rumah tangga di Anjun.

\section{Data, Instrumen, dan Teknik Pengumpulan Data}

\section{a. Sumber Data}

Sumber data yang dibutuhkan dalam penelitian ini atau data yang dikumpulkan di

lapangan meliputi :

1. Data Primer,yaitu data yang dihasilkan dari jawaban angket atau kuisioner, dan wawancara.

2. Data Sekunder, yaitu data tentang keadaan umum para ibu rumah tangga yang berada di daerah Anjun Karawang. Data ini diperoleh dari dokumentasi dan studi pustaka.

\section{b. Teknik skala pengukuran}

Alat ukur data primer bersifat kualitatif, dilakukan dengan menggunakan skala likert

yang kemudian di transformasikan menjadi kuantitatif dengan menggunakan empat jenjang yaitu dengan angka skor yang bernilai mulai dari 1 sampai dengan 4 dan data akan berubah menjadi kuantitatif. Dengan menggunakan program SPSS.

\section{c. Pengujian Validitas dan Reliabilitas}

Pengolahan uji validitas dan reliabilitas dilakukan dengan menggunakan program SPSS. Uji validitas yang dilakukan pada penelitian ini adalah validitas internal yaitu menguji kesesuaian antara bagian-bagian instrument dengan instrument keseluruhan. Sedangkan uji reliabilitas yang dilakukan pada penelitian ini yaitu uji reliabilitas internal dengan menganalisis data dari satu kali pengetesan atau pengujian hasil kuesioner yang diisi oleh responden.

\section{d. Teknik Pengumpulan Data}


Observasi : Metode dimana peneliti mengamati langsung objek yang diteliti.( Kriyantono, $2007: 66$ ).

Interview : sesuai dengan pengertian, interview yang memiliki pengertian sebagai teknik pengumpulan data dengan cara pertukaran verbal tatap muka yang dilakukan oleh seorang pewawancara terhadap respondennya. Pewawancara berupaya untuk memperoleh informasi atau ungkapan - ungkapan pendapat, serta keyakinan dari subjek penelitian ( Maccoby dan Minichiello, dkk. 1995 ).

\section{Teknik Analisis Data}

Analisis data adalah proses mengatur urutan data, mengorganisasikannya ke dalam suatu pola, kategori, dan satuan uraian data. Kegiatan analisis atau analisis data merupakan upaya mencari data secara sistematis dari data catatan hasil observasi, wawancara, dan lainnya untuk meningkatkan pemahaman peneliti tentang kasus yang diteliti dan mengkajinya sebagai temuan data yang valid diperoleh dengan penyederhanaan hasil perolehan data yang dilakukan dengan model interactive yang disusun secara terinci dan sistematis, yaitu langkah - langkah berikut :

1. Reduksi data, merupakan suatu proses dimana data yang diperoleh dari lapangan tersebut dilakukan reduksi, dirangkum, dipilih hal - hal yang pokok, dan difokuskan pada hal - hal yang penting, serta disusun secara sistematis dengan tujuan agar data tersebut menjadi lebih mudah dipahami dan dikendalikan.

2. Display data merupakan tampilan atau laporan yang merupakan informasi yang diperoleh sebagai hasil reduksi data yang memungkinkan adanya penarikan kesimpulan dan pengambilan tindakan.

3. Penarikan kesimpulan / verifikasi, dalam penelitian kualitatif, penarikan kesimpulan telah dilakukan sejak penelitian itu dimulai dimana peneliti mencari makna dari data yang dikumpulkannya dan melakukan penarikan kesimpulan.

\section{HASIL PENELITIAN DAN PEMBAHASAN}

\section{Hasil Penelitian}

\subsection{Perilaku Konsumen}

\subsubsection{Pengertian Perilaku Konsumen}


Perilaku konsumen merupakan suatu proses yang berkaitan erat dengan proses pembelian, pada saat itu konsumen melakukan aktifitas-aktifitas seperti melakukan pencarian, penelitian, dan pengevaluasian produk. Perilaku konsumen merupakan hal-hal yang mendasari konsumen untuk membuat keputusan pembelian. Yang termasuk ke dalam perilaku konsumen selain mengenai kualitas produk, juga meliputi harga produk atau jasa tersebut. Jika harga suatu produk tidak terlalu tinggi, maka konsumen tidak akan terlalu lama membutuhkan waktu untuk memikirkan dan melakukan aktifitas perilaku konsumen. Namun jika harga suatu barang atau jasa tersebut bisa dibilang tinggi, atau mahal, maka konsumen tersebut akan memberikan effort lebih terhadap barang tersebut. Pembeli tersebut akan semakin lama melakukan perilaku konsumen, seperti melihat, menanyakan, mengevaluasi, dan mempertimbangkan.

Berikut adalah beberapa definisi perilaku konsumen menurut para ahli :

\section{a. Menurut Engel, Blackwell dan Miniard}

Perilaku konsumen adalah tindakan-tindakan produk dan jasa, termasuk didalamnya adalah proses keputusan yang mengawali serta mengikuti tindakan pembelian tersebut. Tindakan tersebut adalah terlibat secara langsung dalam proses memperoleh, mengkonsumsi bahkan membuang atau tidak jadi menggunakan suatu produk atau jasa tersebut.

\section{b. Menurut The American Marketing Association}

Perilaku konsumen adalah proses membagai interaksi dinamis dari pengaruh dan kesadaran, perilaku dan lingkungan dimana seseorang melakukan pertukaran aspek kehidupannya.

\section{c. Menurut Mowen}

Perilaku konsumen merupakan aktivitas ketika seseorang mendapatkan, mengkonsumsi atau membuang barang atau jasa pada saat proses pembelian. 


\section{d. Menurut Schiffman dan Kanuk}

Perilaku konsumen adalah suatu proses yang dilalui oleh seorang pembeli dalam mencari, membeli, menggunakan, mengevaluasi serta bertindak pada konsumsi produk dan jasa, maupun ide yang diharapkan dapat memenuhi kebutuhan seseorang tersebut.

\subsubsection{Jenis Perilaku Konsumen}

Jenis-jenis perilaku konsumen ini sendiri berbeda-beda dan bermacammacam. Misalkan Anda ingin membeli buah mangga, maka yang termasuk ke dalam perilaku konsumen sebelum membeli adalah mencium bau mangga tersebut untuk memastikan apakah sudah matang, kemudian meneliti dari bentuknya, apakah ada sisi yang busuk, menekan-nekan mangga tersebut juga untuk memastikan tingkat kematangan mangga tersebut, dan lain sebaginya. Hal ini juga dapat diterapkan pada pembelian produk jangka panjang, misalnya peralatan elektronik, gadget, alat-alat furniture, dan lain sebagainya. Untuk produk jasa, misalkan jasa tour wisata, pasti Anda akan mengecek terlebih dahulu dari testimoni pembeli, track record perusahaan jasa travel itu sendiri, dan lain sebaginya. Pada intinya, setiap konsumen yang akan membeli suatu produk atau menggunakan sebuah jasa, maka konsumen tersebut pasti melakukan apa yang disebut sebagi perilaku konsumen.

Pada dasarnya, perilaku konsumen secara umum dibagi menjadi 2 yaitu perilaku konsumen yang bersifat rasional dan irrasional. Yang dimaksudkan dengan perilaku konsumen yang bersifat rasional adalah tindakan perilaku konsumen dalam pembelian suatu barang dan jasa yang mengedepankan aspekaspek konsumen secara umum, yaitu seperti tingkat kebutuhan mendesak, kebutuhan utama/primer, serta daya guna produk itu sendiri terhadap konsumen pembelinya. Sedangkan perilaku konsumen yang bersifat irrasional adalah perilaku konsumen yang mudah terbujuk oleh iming-iming diskon atau marketing dari suatu produk tanpa mengedepankan aspek kebutuhan atau kepentingan. Untuk lebih jelasnya, berikut beberapa ciri-ciri yang menjadi dasar perbedaan antara perilaku konsumen yang bersifat rasional dan perilaku konsumen yang bersifat irrasional. 
Berikut ini beberapa ciri-ciri dari Perilaku Konsumen yang bersifat Rasional:

1. Konsumen memilih barang berdasarkan kebutuhan

2. Barang yang dipilih konsumen memberikan kegunaan optimal bagi konsumen

3. Konsumen memilih barang yang mutunya terjamin

4. Konsumen memilih barang yang harganya sesuai dengan kemampuan konsumen.

Beberapa ciri-ciri Perilaku Konsumen yang bersifat Irrasional:

1. Konsumen sangat cepat tertarik dengan iklan dan promosi di media cetak maupun elektronik

2. Konsumen memilih barang-barang bermerk atau branded yang sudah dikenal luas

3. Konsumen memilih barang bukan berdasarkan kebutuhan, melainkan gengsi atau prestise

\subsubsection{Proses Pembentukan Perilaku Konsumen}

Perilaku konsumen dilakukan berdasarkan suatu proses sebelum dan sesudah seorang konsumen melakukan proses pembelian suatu barang maupun jasa. Dalam perilaku konsumen tersebut, seorang pembeli akan melakukan penilaian yang kemudian pada akhirnya akan mempengaruhi proses pengambilan keputusannya atas pembelian barang atau jasa tersebut. Berikut beberapa tahapan pengambilan keputusan seorang konsumen :

\section{Pengenalan Masalah.}

Biasanya seorang konsumen melakukan pembelian atas dasar kebutuhan atau untuk menyelesaikan keperluan, masalah dan kepentingan yang dihadapi. 
Jika tidak ada pengenalan masalah terlebih dahulu, maka konsumen juga tidak akan tahu produk mana yang harus dibeli.

\section{Pencarian Informasi.}

Setelah mengetahui permasalahan yang dialami, maka pada saat itu seorang konsumen akan aktif mencari tahu tentang bagaimana cara penyelesaian masalahnya tersebut. Dalam mencari sumber atau informasi, seseorang dapat melakukannya dari diri sendiri (internal) maupun dari orang lain (eksternal) seperti masukan, sharing pengalaman, dan lain sebagainya.

\section{Mengevaluasi Alternatif.}

Setelah konsumen mendapatkan berbagai macam informasi yang dibutuhkan dalam pengambilan keputusan, maka hal selanjutnya yang dilakukan oleh konsumen tersebut adalah mengevaluasi segala alternatif keputusan maupun informasi yang diperoleh. Hal itu lah yang menjadi landasan dalam mengatasi permasalahan yang dihadapi.

\section{Keputusan Pembelian.}

Proses selanjutnya setelah melakukan evaluasi pada alternatif-alternatif keputusan yang ada adalah konsumen tersebut akan melalui proses yang disebut dengan keputusan pembelian. Waktu yang diperlukan dalam proses pengambilan keputusan ini tidak sama, yaitu tergantung dari hal-hal yang perlu dipertimbangkan dalam proses pembelian atau pengambilan keputusan tersebut.

\section{Evaluasi Pasca-Pembelian.}

Proses lanjutan yang biasanya dilakukan seorang konsumen setelah melakukan proses dan keputusan pembelian adalah mengevaluasi pembeliannya tersebut. Evaluasi yang dilakukan mencakup pertanyaan-pertanyaan mendasar seperti apakah barang tersebut sudah sesuai dengan harapan, sudah tepat guna, tidak mengecewakan, dan lain sebagainya. Hal ini akan menimbulkan sikap kepuasan dan ketidakpuasan barang oleh konsumen, mengecewakan dan tidak 
mengecewakan. Hal tersebut akan berdampak pada pengulangan pembelian barang atau tidak. Jika barang memuaskan dan tidak mengecewakan, maka konsumen akan mengingat merk produk tersebut sehingga akan terjadi pengulangan pembelian di masa mendatang. Namun jika barang tidak memuasakan dan mengecewakan, maka konsumen juga akan mengingat merk barang tersebut dengan tujuan agar tidak mengulang kembali membeli barang tersebut di masa yang akan datang.

\subsubsection{Cara Mengenali Perilaku Konsumen}

Dalam disiplin ilmu ekonomi terdapat 3 pendekatan untuk mengenali perilaku konsumen, pendekatan-pendekatan tersebut adalah sebagai berikut :

1. Pendekatan Interpretif.

Pendekatan ini adalah pendekatan yang membahas secara mendalam halhal mendasar mengenai perilaku konsumen. Dalam pendekatan ini menggunakan teknik observasi langsung yaitu menggunakan teknik wawancara yang dilakukan secara mendalam dan menyeluruh. Selain wawancara, pendekatan ini juga mengutamakan focus group discussion. Semua hal tersebut dilakukan untuk mendapatkan kesimpulan mengenai makna suatu produk atau jasa bagi konsumen, serta perasaan yang dialami konsumen ketika membeli kemudian menggunakan produk maupun jasa tersebut.

2. Pendekatan Tradisional yang didasari pada teori dan metode dari Ilmu Psikologi Kognitif, Sosial dan Behavioral serta Ilmu Sosiologi.

Pendekatan ini menggunakan studi lapangan berupa eksperimen yang didukung dengan survey dengan tujuan untuk menguji hipotesa penelitian yang berkaitan dengan teori. Kemudian dicari sebuah pemahaman mengenai proses seorang konsumen menganalisa beberapa informasi, membuat keputusan, dan pengaruh lingkungan sosial terhadap perilaku konsumen tersebut. Tujuan utama dari pendekatan ini adalah untuk mengembangkan teori dan metode yang relatif. Yang mana akan digunakan untuk menjelaskan perilaku konsumen serta pembuatan keputusan konsumen. 
3. Pendekatan Sains Pemasaran yang didasari pada teori dan metode dari Ilmu Ekonomi dan Statistika.

Penelitian dalam pendekatan ini menggunakan pengembangan teori dari Abraham Maslow yaitu Teori Hierarki Kebutuhan Maslow. Teori tersebut berisi tentang hierarki kebutuhan manusia yang kemudian diuji coba dengan model Ilmu Matematika. Pendekatan ini dilakukan untuk memprediksi moving rate analysis atau pengaruh startegi marketing terhadap pilihan dan pola konsumsi.

Semua pendekatan yang dijelaskan diatas mempunyai nilai-nilai tertentu yang dapat memberikan pemahaman mengenai perilaku konsumen. Selain itu dapat pula diterapkan untuk strategi marketing jika dilihat dari tingkatan maupun sudut pandang analisis yang berbeda-beda. Ketiga pendekatan ini dapat digunakan oleh suatu pemilik bisnis atau perusahaan, baik dengan menggunakan salah satu dari pendekatan tersebut maupun dengan menggunakan ketiga pendekatan sekaligus. Semuanya tergantung dari jenis-jenis masalah yang dihadapi oleh masing-masing bisnis dan suatu perusahaan.

\subsection{Penjualan Online}

\subsubsection{Pengertian Penjualan Online}

Secara sederhana pemasaran online atau sering disebut sebagai pemasaran digital diartikan sebagai strategi pemasaran yang memanfaatkan internet. Kegiatan pemasaran untuk mendapatkan perhatian konsumen dilakukan dengan memanfaatkan media sosial, website, email, bahkan augmented reality. Hal ini dapat dilakukan dengan iklan berbayar, konten berkualitas atau sekadar posting-an sederhana melalui media online.

Banyaknya aktivitas dan interaksi yang terjadi di dunia internet, membuat banyak sekali pemilik bisnis yang mengandalkan cara ini untuk meningkatkan nilai jual produknya. Satu posting-an di internet dapat diakses oleh ratusan juta orang di seluruh dunia. Jadi, dari mana pun Anda berbisnis, 
akan tetap mampu mendapatkan perhatian secara global jika telah memasuki dunia internet.

\subsubsection{Jenis-Jenis Saluran Pemasaran Online}

Berikut beberapa jenis saluran yang dapat digunakan dalam melakukan pemasaran online.

\section{Media Sosial}

Menjangkau konsumen melalui iklan berbayar atau posting-an organik dengan memanfaatkan media-media seperti Facebook, Twitter, Instagram dan lain sebagainya.

\section{Search Engine Optimization (SEO)}

Mengoptimasi website dengan berbagai konten untuk mendapatkan peringkat teratas di hasil pencarian mesin pencari.

\section{Email Pemasaran}

Pesan komersil seperti promo, penawaran produk, diskon, penawaran membership dan lain sebagainya secara personal dengan menggunakan media email.

\section{Search Engine Marketing (SEM)}

Bentuk lain dari pemasaran online berbayar. Anda melakukan pembayaran kepada mesin pencari untuk mendapatkan visibilitas website di mesin pencari tersebut.

\section{Pemasaran Afiliasi}

Pemasaran menggunakan afiliasi atau mitra penjualan yang diminta untuk menempatkan iklan bisnis Anda di website atau media sosial mereka.

\section{Influencer Marketing}

Melakukan pemasaran melalui ahli industri atau sosok yang dipercaya oleh konsumen ketika melakukan promosi, iklan atau ulasan terhadap produk. 


\section{Pemasaran Konten}

Pemasaran dengan membuat konten mengenai produk atau layanan Anda dan mempromosikannya di berbagai channel untuk menjangkau konsumen potensial.

\section{Lead Generation}

Menghasilkan konversi lebih dari orang yang berkunjung ke website Anda, seperti menghasilkan penjualan dari mereka dan mendapatkan alamat email calon konsumen.

\section{Google Ads}

Google Ads merupakan platform iklan online yang dikembangkan oleh Google, pengiklan membayar untuk menampilkan iklan singkat, penawaran layanan, daftar produk, konten video dan menghasilkan pemasangan aplikasi seluler dalam jaringan iklan Google kepada pengguna web.

\section{Pengoptimalan Web}

Proses menggunakan eksperimen terkontrol untuk meningkatkan kemampuan situs web untuk mendorong sasaran bisnis. Untuk meningkatkan kinerja situs web mereka, pemilik situs web menerapkan pengujian A / B untuk bereksperimen dengan variasi pada laman situs web mereka untuk menentukan perubahan mana yang pada akhirnya akan menghasilkan lebih banyak konversi.

\subsubsection{Keuntungan atau Manfaat Penjualan Online}

\section{- $\quad$ Mengurangi Biaya}

Ini adalah alasan utama mengapa banyak pemilik bisnis yang lebih memilih melakukan pemasaran online dibandingkan dengan pemasaran offline. Penggunaan media sosial, website dan media internet lainnya kebanyakan tidak dikenakan biaya. Meskipun Anda menggunakan iklan berbayar secara online, biaya yang dikeluarkan relatif lebih hemat jika dibandingkan dengan memasang iklan di televisi, radio, koran atau mencetak flyer dalam jumlah yang banyak. 
Pay per click juga merupakan cara terbaik untuk menghemat dan mengawasi biaya karena pembayaran didasarkan pada klik nyata yang didapat iklan Anda. Berbeda dengan iklan media konvensional dengan biaya cukup mahal namun Anda bahkan tidak mengetahui berapa orang yang benar-benar memperhatikan.

\section{- Dapat Diukur Real Time}

Pemasaran yang dilakukan secara online mudah diukur melalui alat analisis seperti Google Analytics. Sehingga informasi tentang klik, kunjungan dan penjualan dari SEO, AdWords, media sosial, konten serta pemasaran email yang dibuat bisa didapatkan.

Walaupun ini merupakan proses yang panjang tetapi Anda dapat melihat hasilnya secara real time setelah metode ini diaplikasikan. Dengan cara ini, efisiensi strategi Anda dapat diukur dan perubahan dapat segera diimplementasikan.

\section{- $\quad$ Cepat Menentukan Target}

Dengan kecanggihan teknologi pemasaran saat ini, Anda dapat menyasar dengan tepat calon konsumen yang memang tertarik atau membutuhkan produk Anda. Teknologi saat ini mampu membuat calon konsumen memberikan informasi mereka secara sukarela sehingga Anda dapat melacak apa yang memang mereka butuhkan secara tepat.

\section{- Paparan Jangka Panjang}

Promosi yang dilakukan melalui pemasaran offline biasanya hanya bertahan selama 1-4 minggu. Hal ini berbeda dengan pemasaran online yang merupakan proses berkelanjutan. Di situs pencarian, konten promosi Anda akan 
tetap terlihat oleh konsumen untuk jangka waktu yang lama. Namun Anda perlu melakukan sedikit pembaruan agar konten tersebut tetap terlihat menarik.

Hampir seluruh pemilik bisnis saat ini menggunakan pemasaran online secara digital. Hal ini juga berlaku dalam pengelolaan keuangan bisnis. Pengelolaan keuangan bisnis yang dilakukan secara manual justru akan semakin memperlambat dan mempersulit jalannya manajemen bisnis.

\subsection{Pandemi Covid-19}

\section{2..3.1 Pengertian Pandemi Covid-19}

Virus Corona atau Covid-19 adalah sejenis virus mematikan yang berukuran sangat kecil dan tidak bisa dilhat oleh mata secara langsung. Penyakit ini disebabkan oleh korona virus jenis baru yang diberi nama SARS-CoV. Wabah virus ini muncul pertama kalinya di kota Wuhan, China, pada bulan Desember 2019. Virus ini diduga menyebar diantara orang - oaring melalui percikan pernafasan ( droplet ) yang dihasilkan selama batuk, bersin, ataupun berbicara. Selain itu juga dapat disebarkan melalui sentuhan permukaan benda yang sudah terkontaminasi.

\subsubsection{Dampak Pandemi Covid-19}

Penyebaran virus corana yang begitu cepat dan menyebabkan kematian yang sangat tinggi, pada akhirnya memberikan dampak bagi semua aktifitas dan kegiatan tidak hanya keseharian namun secara menyeluruh, pada kegiatan luar rumah. Baik secara kegiatan pendidikan /sekolah, pekerjaan, maupun kegiatan lainnya yang memerlukan keluar rumah.

Pemerintah Membuat Beragam Kebijakan untuk mengurangi bertambahnya penyebaran virus corona. Mulai dari kebijakan, larangan keluar masuk Negara Indonesia, larangan berkumpul, stay at home. Stay at home yaitu Isolasi Diri, social distancing, hingga Karantina Wilayah. Karantina Wilayah merupakan kebijakan yang di ambil dalam kondisi sangat darurat. Beberapa Kota dan Kabupaten telah memberlakukan Pembatasan Sosial Berskala Besar (PSBB) untuk mencegah penyebaran Virus Covid-19 harus dilakukan 
Social Distancing (Jarak Sosial) atau dikenal juga dengan upaya Lockdown (Karantina Wilayah).

\section{Hasil Pengujian Validitas dan Reliabilitas}

\section{Uji Validitas}

Dalam menentukan valid tidaknya data dilakukan dengan melihat hasil dari korelasi ( nilai r ) setiap item data tersebut, dengan kriteria sebagai berikut :

- Jika $r$ hasil positif, serta $r$ hasil $>r$ table, maka butir atau variable tersebut valid. Hasil dari uji validitas dan reliabilitas dinyatakan bahwa semua data dan item pertanyaan semuanya valid dan reliable.

- Jika $\mathrm{r}$ hasil negative, dan $\mathrm{r}$ hasil $<\mathrm{r}$ table, maka butir atau variable tersebut tidak valid.

Uji validitas yang dilakukan adalah dengan menguji semua variable pertanyaan yang terbagi kedalam empat kelompok kuisioer terhadap responden. Hasil perhitungan validitas menggunakan program SPSS dapat dilihat pada table dibawah ini :

Tabel 1

\section{Hasil Uji Validitas}

\begin{tabular}{|l|r|r|r|r|}
\hline \multicolumn{7}{|c|}{ Item-Total Statistics } \\
\hline & $\begin{array}{l}\text { Scale Mean if } \\
\text { Item Deleted }\end{array}$ & $\begin{array}{r}\text { Scale Variance } \\
\text { if Item Deleted } \\
\text { Torrected Item- } \\
\text { Total Correlation }\end{array}$ & $\begin{array}{c}\text { Cronbach's } \\
\text { Alpha if Item } \\
\text { Deleted }\end{array}$ \\
\hline Item_1 & 10.00 & 4.368 & .772 & .564 \\
\hline Item_2 & 10.33 & 4.368 & .878 & .564 \\
\hline Item_3 & 11.53 & 1.499 & .581 & .403 \\
\hline Item_4 & 11.43 & 3.771 & .797 & .328 \\
\hline Item_5 & 12.70 & 4.631 & .368 & .504 \\
\hline
\end{tabular}




\section{Keterangan :}

$$
\begin{array}{ll}
\mathrm{N}=30 & \alpha=5 \%(0.05) \\
\mathrm{df}=\mathrm{n}-\mathrm{k}-1 \mathrm{df}=\mathrm{n}-2 & \mathrm{r} \text { table }=0.3610 \\
\mathrm{df}=30-2 & \mathrm{df}=28
\end{array}
$$

\section{Kesimpulan :}

Dari hasil output SPSS tersebut diatas dinyatakan semua data adalah valid karena semua memiliki $r$ hasil di atas $r$ table $(r$ table $=0.3610$ dengan tingkat signifikansi $5 \%$ dan $\mathrm{df}=28$ ).

\section{Uji Reliabilitas}

Apabila data dinyatakan valid, maka nilai alpha dari pengujian tersebut digunakan untuk mengetahui reliabilitas data dengan kriteria sebagai berikut : - Jika $\mathrm{r}$ alpha positif dan $\mathrm{r}$ alpha $>\mathrm{r}$ table, maka butir atau variable tersebut reliable.

- Jika $\mathrm{r}$ alpha negative dan $\mathrm{r}$ alpha $<\mathrm{r}$ table, maka butir atau variable

\begin{tabular}{|c|c|}
\hline $\begin{array}{c}\text { Cronbach's } \\
\text { Alpha }\end{array}$ & $\mathrm{N}$ of Items \\
\hline .587 & 5 \\
\hline
\end{tabular}
tersebut tidak reliable.

Hasil pengujian reliabilitas diperoleh :

Tabel 2

Hasil Uji Reliabilitas

Reliability Statistics

Berdasarkan hasil output SPSS semua data tersebut diatas dinyatakan reliable karena semua data memiliki $r$ alpha positif dan lebih besar dari $r$ table ( r alpha $>0.3610)$ 


\section{Pembahasan}

\section{Gambaran Umum Ibu Rumah Tangga Di Wilayah Anjun Karawang}

Anjun merupakan desa yang terletak di kelurahan Karawang Kulon, Kecamatan Karawang Barat, Kabupaten Karawang. Desa Anjun terbagi kedalam tiga wilayah, yaitu Anjun Kidul, Anjun Kaler dan Anjun Kanoman. Dimana pada wilayah Anjun Kanoman yang penulis teliti terdapat 2 RW yaitu RW 05 dan RW 012. Hal ini sesuai yang disampaikan oleh bapak Ato selaku ketua RW 012.

Dalam penelitian ini penulis melakukan penelitian di wilayah Anjun Kanoman , dengan mengambil pada satu Rukun Warga yaitu RW 012, dan mengambil responden 100 ibu rumah tangga, yang tidak bekerja, pada rentang usia dari 25 tahun sampai dengan 40 tahun.

\section{Hasil Riset Peneltian}

Berdasarkan hasil pengumpulan data yang dilakukan melalui penyebaran angket kepada 100 responden ibu rumah tangga, dimana jawaban responden yang telah penulis terima ditemukan informasi tentang tanggapan pada masingmasing pertanyaan. Untuk masing-masing pertanyaan angket diperoleh hasil sebagai berikut :

\subsubsection{Karateristik Responden}

Berdasarkan hasil data yang kami teliti, responden yang berasal dari ibu-ibu rumah tangga ini di bedakan sesuai karakteristik :

\section{- Usia}

Usia 25-30 tahun berjumlah 43 responden

Usia 31-35 tahun berjumlah 39 responden

Usia 36-40 tahun berjumlah 18 responden

- $\quad$ Pendapatan suami

Kurang dari Rp 2.000.000 berjumlah 10 responden

Antara Rp 2.000.000 - Rp 5.000.000 berjumlah 47 responden

Lebih dari Rp 5.000.000 berjumlah 43 responden 


\subsubsection{Pengetahuan Responden}

Berdasarkan hasil analisis dari 100 responden, didapatkan hasil bahwa hampir seluruh responden (83 responden) sudah mengetahui pembelanjaan secara online, sebanyak 7 responden mengaku tidak mengetahui pembelanjaan secara online, sedangkan sisanya sebesar 10 responden merasa ragu-ragu dengan pembelanjaan secara online.

Tabel 4.3

Distribusi Pengetahuan Responden

\begin{tabular}{clcc}
\hline \multirow{2}{*}{ No } & \multirow{2}{*}{ Pengetahuan Responden } & \multicolumn{2}{c}{ Jumlah } \\
& & N & \% \\
\hline 1. & Ya mengetahui & 83 & 83 \\
2. & Tidak mengetahui & 7 & 7 \\
3. & Kurang mengetahui & 0 & 0 \\
4. & Ragu-ragu & 10 & 10 \\
\hline \multicolumn{2}{r}{ Total } & 100 & 100 \\
\hline
\end{tabular}

Selanjutnya yang akan menjadi responden dalam penelitian ini sebanyak 83 ibu-ibu rumah tangga yang sudah memiliki pengetahuan mengenai pembelanjaan secara online.

\subsubsection{Penggunaan Pembelanjaan Online}

Pertanyaan no 2. Apakah ibu-ibu suka menggunakan pembelanjaan secara online disaat pandemic covid-19, diperoleh jawaban 72 responden menjawab Ya, sedangkan 11 responden menjawab kadang-kadang. Total dari 83 responden, sesuai dengan pernyataan pada butir pertanyaan no 1 .

\subsubsection{E-commerce Pembelanjaan Online}

Pertanyaan no 3. Dimanakah ibu-ibu menggunakan pembelanjaan secara online, diperoleh jawaban 27 responden memilih Grab dan GoFood, sedangkan 32 responden memilih Shopee, sedangkan 14 responden memilih Toko Pedia,dan 10 responden memilih Lazada. 


\subsubsection{Produk Yang Diminati Pembelanjaan Online}

Pertanyaan no 4. Barang atau produk apakah yang suka dibeli pada pembelanjaan online. Sebanyak 56 responden menjawab melakukan pembelanjaan online untuk kebutuhan baju, sepatu tas, dan sebanyak 27 responden melakukan pembelanjaan online untuk makanan jadi atau kuliner.

\subsubsection{Frekuensi Pembelanjaan Online}

Pertanyaan no 5, berapa kali kah ibu-ibu melakukan pembelanjaan secara online dalam sebulan disaat pandemic, 52 responden menjawab lebih dari dua kali sedangkan 31 responden menjawab maksimal 2 kali dalam sebulan.

\subsection{Pembahasan}

Dari hasil jawaban yang penulis peroleh menunjukkan sebanyak 72 responden yang melakukan pembelanjaan secara online disaat pandemic, baik itu untuk pembelanjaan kebutuhan tas, sepatu, baju juga makanan atau kuliner. Dan 52 responden menjawab lebih dari dua kali melakukan pembelanjaan secara online. Hal ini berarti dari 100 responden ibu-ibu rumah tangga di wilayah Anjun Kanoman yang suka melakukan pembelanjaan online disaat pandemic mencapai $72 \%$, dan pembelanjaan online yang dilakukan dalam sebulan mencapai $52 \%$.

Dari hasil wawancara yang penulis lakukan terhadap beberapa ibu rumah tangga yaitu Ibu Nenden, Umi Rara, dan Ibu Rifa mereka menyatakan memang disaat covid seperti ini merasa aman belanja secara online, bahkan sering kali berbelanja online tidak hanya untuk makanan atau kuliner tapi seperti baju, sandal, sepatu bahkan kebutuhan harian lainnya, justru jauh lebih murah dan adanya berbagai macam diskon. Rata - rata dalam sebulan mereka melakukan pembelian online 6 sampai 10 kali, dikarenakan merasa lebih aman, mudah,nyaman dan fasilitas lainnya yang ditawarkan penyedia e-commerce yang pada akhirnya membuat mereka semakin sering berbelanjan online dibandingkan offline. Ada salah satu ibu rumah tangga yang bernama Lia justru hampir semua kebutuhan hariannya dibeli melalui online, seperti perlengkapan make-up, peralatan mandi bahkan belanjan bulannan, Ibu Lia bahkan membeli 
furniture malalui online dengan alasan yang memang selain harganya murah juga karna alasan keamanan jika harus keluar rumah khawatir tertular covid sehingga dia lebih banyak melakukan pembelian secara online.

Respon dari responden tentang pembelanjaan secara online ini juga ternyata meliputi pilihan produk, merk,serta waktu yang bebas dilakukan kapan saja, dan bahkan system COD atau Cash On Delivery, dimana barang datang dan baru dibayar membuat para ibu-ibu rumah tangga di wilayah Anjun Kanoman ini semakin menyukai pembelanjaan secara online. Banyaknya penawaran diskon, gratis ongkos kirim juga termasuk salah satu yang menarik minat beli mereka pada pembelanjaan onlinenya. Hal ini disampaikan oleh Ibu Dedeh yang memang dari sebelum covid pun sudah sering belanja online, terlebih saat ini di masa pandemic, ia semakin lebih menyukai belanja online dibandingkan offline.

\section{KESIMPULAN DAN IMPLIKASI}

Setelah dilakukan penelitian dapat disimpulkan bahwa dimasa pandemic saat ini ibu-ibu rumah tangga wilayah Anjun Kanoman sangat menyukai pembelanjaan secara online. Bahkan dengan banyak nya fasilitas dan kemudahan yang ditawarkan dari para e-commerce membuat para ibu rumah tangga ini lebih sering melakukan pembelanjaan nya melalui online dibandingkan dengan berbelanja secara langsung ke toko atau swalayan. Banyak factor yang membuat para ibu rumah tangga ini beralih pada pembelanjaan onlinenya salah satu nya dimasa pandemic ini tentu saja karna khawatir tertular virus corona.

Bagaimanapun penelitian ini masih memiliki banyak keterbatasan, khususnya rentang waktu yang dilakukan penelitian hanya sekitar 4 ( empat ) bulan saja. Jadi kemungkinan hasil yang diperoleh belum maksimal. Dan juga keterbatasan ruang lingkup pertanyaan pembelanjaan online nya yang mungkin belum terlalu luas. Sehingga dapat dimungkinkan untuk melakukan kembali kajian penelitian yang sejenis namun dengan keluasan ruang lingkup pertanyaan tentang pembelanjaan online nya serta kecukuppan rentang waktu untuk menelitinya ditambahkan kembali agar lebih maksimal hasil nya. 


\section{DAFTAR PUSTAKA}

Anang firmansyah, Dr : Perilaku Konsumen, 2018, Yogyakarta

Budi Santoso, DRS.,MM :'Riset Perilaku Konsumen Studi Mengenai Perilaku Konsumen Terhadap Online Shopping"

Gorbalenya, Alexander E, 11 Februari 2020, Severe Accute Respirotory

Syndrome Related Corana Virus, The Species and Its Viruses, a statement of the corona virus Study Group.

J. Paul Peter : Perilaku Konsumen Dan Strategi Pemasaran,2013, Salemba Empat.

Kincard, Judith, 2003 : Customer Relationship Management, Gething 11 Right Prentice. Hall.Inc 